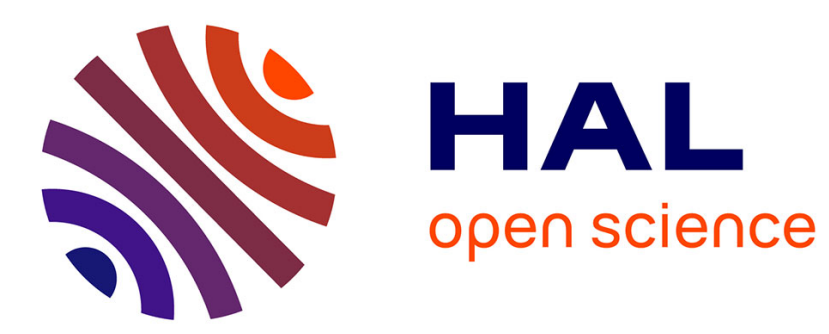

\title{
A physicochemical interpretation of the photoconductivity of a-Si : $\mathbf{H}$
}

H. Hamdi, A. Deneuville, J.C. Bruyère

\section{To cite this version:}

H. Hamdi, A. Deneuville, J.C. Bruyère. A physicochemical interpretation of the photoconductivity of a-Si : H. Journal de Physique Lettres, 1983, 44 (7), pp.265-269. 10.1051/jphyslet:01983004407026500 . jpa-00232191

\section{HAL Id: jpa-00232191 https://hal.science/jpa-00232191}

Submitted on 1 Jan 1983

HAL is a multi-disciplinary open access archive for the deposit and dissemination of scientific research documents, whether they are published or not. The documents may come from teaching and research institutions in France or abroad, or from public or private research centers.
L'archive ouverte pluridisciplinaire HAL, est destinée au dépôt et à la diffusion de documents scientifiques de niveau recherche, publiés ou non, émanant des établissements d'enseignement et de recherche français ou étrangers, des laboratoires publics ou privés. 
Classification

Physics Abstracts

$73.60 \mathrm{~F}-81.40-72.40$

\title{
A physicochemical interpretation of the photoconductivity of a-Si : $\mathbf{H}$
}

\author{
H. Hamdi, A. Deneuville and J. C. Bruyère \\ Groupe des Transitions de Phases, C.N.R.S., B.P. 166, 38042 Grenoble Cedex, France
}

(Reçu le 18 novembre 1982, révisé le 27 janvier 1983, accepté le 14 février 1983)

\begin{abstract}
Résumé. - Dans les films de a-Si : $\mathrm{H}$ pulvérisés, le contenu total en hydrogène et sa répartition sur les sites $\mathrm{SiH}, \mathrm{SiH}_{2}$ ou $\mathrm{H}^{\prime}$ varient avec la posthydrogénation. On constate que la concentration de liaisons libres reste constante. Ces résultats peuvent être expliqués par une diffusion préférentielle de l'hydrogène à l'intérieur de la zone tissu, alors que les liaisons libres sont localisées dans la zone îlot. La photoconductivité est contrôlée par les défauts sans spin du tissu et décroît si le contenu relatif en sites $\mathrm{SiH}_{2}$ augmente.
\end{abstract}

\begin{abstract}
Total hydrogen content and its distribution among $\mathrm{SiH}, \mathrm{SiH}_{2}$ and other $\mathrm{H}^{\prime}$ sites of sputtered a-Si : $\mathbf{H}$ films vary after posthydrogenation but the dangling bond concentrations remain constant. This can be explained by preferential $\mathbf{H}$ diffusion in the tissue zone where most of the hydrogen is located, while the residual dangling bonds are in the islands. The photoconductivity is controlled by spinless defects of the tissue zone originating from back defects of $\mathrm{H}$ on their various sites. It decreases as the relative $\mathrm{SiH}_{2}$ content increases.
\end{abstract}

The localized states in sputtered a-Si : $\mathrm{H}$ can be introduced by $\mathrm{Si}$ " structural " defects either connected only to the disorder in the $\mathrm{Si}$ atom positions (pure Si matrix defects) or connected with one or several hydrogen sites (H related defects) [1]. It is important to distinguish between them before making further attempts to decrease their density. Systematic variations of the deposition conditions change continuously the concentration and the nature of both pure $\mathrm{Si}$ matrix defects and $\mathrm{H}$ related defects [2]. However, posthydrogenation [3] drastically changes the concentration of $\mathrm{H}$ on its various sites. There is now more and more evidence that a-Si : $\mathrm{H}$ is an inhomogeneous material [4] with two parts less disordered islands embedded in a more disordered connective tissue. In this case, the photoconductivity might be controlled predominantly by one part of the film, as other properties are [5]. From NMR measurements, most of the hydrogen stays in the more disordered connective tissue, while $[\mathrm{H}]$ concentration in the island is weak $(\sim 3 \%)$ and rather independent of the preparation conditions [4]. From the comparison of the photoconductivity before and after posthydrogenation, which changes strongly the structure of the tissue, we can check whether the photoconductivity is strongly sensitive to this part of the film or not.

We want also to correlate the electronic nature of the localized states (trap or recombination 
centre) with their origin (pure Si matrix defect or such a $\mathrm{H}$ site). This correlation is derived from the comparison of the spin density and steady state photoconductivity with the concentration of the various hydrogen sites before and after hydrogenation.

There is little work done on the connection between physicochemical characteristics and photoconductivity in a-Si : H. For glow discharge material, Anderson and Spear [6] proposed the dominant effect of the electron life time, controlled by the density of positively charged states in the $E_{\mathrm{y}}$ tail just above the electron quasi-Fermi level. Antibonding states of the weak bonds occurring in divacancy type defects were suggested by Spear [7] as the origin of $E_{\mathbf{y}}$. For intrinsic sputtered a-Si : H, Moustakas [8] reported basically the same maximum photoconductivity value as for intrinsic " glow discharge " material, but gave no information about its connection with the remaining defects in the material.

We show here, for the first time, a relationship between the number of some defects and the intensity of the photoconductivity in intrinsic sputtered a-Si : H. Posthydrogenation drastically changes the photoconductivity and the $\mathrm{H}$ concentrations while the dangling bond concentration remains constant. From the dominant $\mathbf{H}$ concentration in the tissue, this indicates that photoconductivity is mainly controlled by $\mathrm{H}$ related spin-free defects in the tissue, and suggests that residual dangling bonds are in the islands.

\section{Experimental results.}

a-Si : $\mathbf{H}$ films are deposited in the same run by RF diode sputtering of a silicon target in a $20 \%$ $\mathrm{H}_{2} / 80 \%$ Ar reactive gas onto fused silica (photoconductivity, optical, electrical measurements and E.P.R.) and high resistivity silicon (E.P.R. nuclear reaction and infrared) substrates at $190^{\circ} \mathrm{C}$. The films are assumed to be nearly identical on fused silica and $\mathrm{c}-\mathrm{Si}$, because they exhibit the same thickness and refractive index from optical (on silica) and I-R (on c-Si) transmission. Their thicknesses are kept around $0.9 \mu$. Posthydrogenation is achieved in situ by leaving the film in contact with the plasma at low RF power at $190^{\circ} \mathrm{C}$ for $1 \mathrm{~h}$. $[\mathrm{H}]$ is nearly constant versus the depth in the film [3].

Using infrared studies, hydrogen can be found within a-Si : $\mathrm{H}$ on different sites, $\mathrm{SiH}\left[\mathrm{H}_{1}\right]$, $\mathrm{SiH}_{2}$ or $\left(\mathrm{SiH}_{2}\right)_{n}\left[\mathrm{H}_{2}\right]$ and $\mathrm{SiH}_{3}[9,10]$. A comparison of infrared (after calibration) and nuclear reaction studies indicates other sites $\mathrm{H}^{\prime}[1-3]$ not seen in infrared, and we do not find the $2140 \mathrm{~cm}^{-1}$ stretching modes attributed to $\mathrm{SiH}_{3}$. The concentrations of $[\mathrm{H}](\bullet),\left[\mathrm{H}_{1}\right](\boldsymbol{\Delta})$ and $\left[\mathrm{H}_{2}\right](\Delta)$ versus the deposition rate are shown in figure 1 for virgin (solid line) and posthydrogenated films (dotted line). The results are internally coherent $\left(\left[\mathrm{H}_{1}\right]+\left[\mathrm{H}_{2}\right]<[\mathrm{H}]\right)$ within the experimental uncertainty. The validity of this comparison was discussed previously [2]. After posthydrogenation, for $v \sim 27 \AA / \mathrm{min}$., the total $[\mathrm{H}]$ concentration is weakly changed but its distribution between $\mathrm{SiH}$ and $\mathrm{SiH}_{2}$ is inverted (becomes $\mathrm{SiH}_{2}$ dominant). For $v \sim 67 \AA / \mathrm{min}$., the total [H] concentration increases while the $\mathrm{SiH}$ and $\mathrm{SiH}_{2}$ concentration remain constant. For $v \sim 150 \AA / \mathrm{min}$., the total $[\mathrm{H}]$ concentration decreases and is only in $\mathrm{SiH}$ sites.

The photoconductivity and conductivity are measured in a coplanar geometry between two pre-evaporated chromium-antimony electrodes $2 \mathrm{~mm}$ apart with an applied voltage of $50 \mathrm{~V}$ and monochromatic illumination by a CODERG grating monochromator. The illumination level is low $\left(\sim 10^{15}\right.$ photons $\left./ \mathrm{cm}^{2}\right)$ leading to low photoelectric currents in the range $10^{-9}$ to $10^{-12}$ A (lower than or equal to the dark current) measured by a Keithley 616 electrometer. Table II shows the variation of the maximum value of the photoconductivity (versus photon energy) versus the deposition rate for $10^{15}$ incident photons $/ \mathrm{cm}^{2}$ for films deposited on fused silica. Similar maximum values of the photoconductivity are obtained for virgin films deposited at low rate (a) $v=25 \AA / \mathrm{min} . \sigma_{\mathrm{ph}} \simeq 2 \times 10^{-7}(\Omega \mathrm{cm})^{-1}$ and for posthydrogenated films deposited at mean rate $\left(\mathrm{b}^{\prime}\right) v \simeq 67 \AA / \mathrm{min} . \sigma_{\mathrm{ph}} \simeq 1.5 \times 10^{-7}(\Omega \mathrm{cm})^{-1}$. The lowest value is obtained for the virgin film deposited at high rate $(\mathrm{c}) v \simeq 145 \AA / \mathrm{min} . \sigma_{\mathrm{ph}} \simeq 8 \times 10^{-10}(\Omega \mathrm{cm})^{-1}$ three orders of magnitude below the maximum values. Virgin films deposited at mean deposition rate (b) 


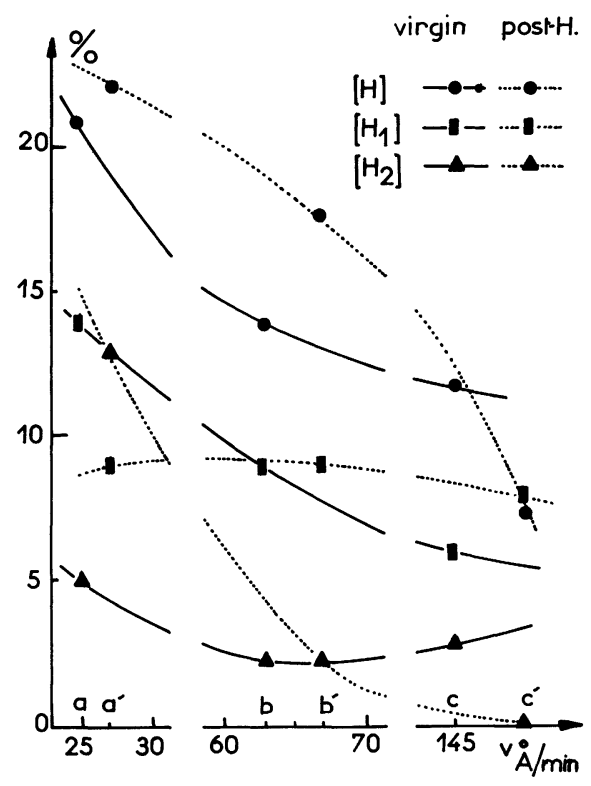

Fig. 1. - Concentration of hydrogen on $[\mathrm{H}](\bullet),\left[\mathrm{H}_{1}\right](\boldsymbol{\nabla})$ and $\left[\mathrm{H}_{2}\right](\Delta)$ versus the deposition rate, for virgin and posthydrogenated films.

Table I. - Spin density and activation energy in the dark, for virgin and posthydrogenated films.

\begin{tabular}{|c|c|c|c|c|}
\hline Treatment & & $\begin{array}{l}\text { Deposition } \\
\text { rate }\end{array}$ & Spins & $E_{c}-E_{F}$ \\
\hline \multirow{2}{*}{$\begin{aligned} & \text { Virgin } \\
+ & 1 \text { h. plasma }\end{aligned}$} & $\mathbf{a}$ & $25 \AA / m i n$ & $1 \quad 10^{15}$ & $0.75 \mathrm{ev}$ \\
\hline & $a^{\prime}$ & $27 \AA / m i n$ & 11015 & $0.64 \mathrm{eV}$ \\
\hline \multirow{2}{*}{$\begin{array}{l}\text { Virgin } \\
+1 \mathrm{~h} . \text { plasma }\end{array}$} & $\mathrm{b}$ & $63 \AA / \mathrm{min}$ & $\begin{array}{ll}6 & 1016\end{array}$ & $0.63 \mathrm{eV}$ \\
\hline & $b^{\prime}$ & $67 \AA / m i n$ & $\begin{array}{ll}7 & 10^{16}\end{array}$ & $0.66 \mathrm{eV}$ \\
\hline \multirow{2}{*}{$\begin{array}{c}\text { Virgin } \\
+1 \mathrm{~h} . \text { plasma }\end{array}$} & c & $145 \AA / m i n$ & $2.5 \quad 10^{17}$ & $0.62 \mathrm{eV}$ \\
\hline & $c^{\prime}$ & $151 \AA / \mathrm{min}$ & $\begin{array}{ll}1.6 & 10^{17}\end{array}$ & $0.65 \mathrm{ev}$ \\
\hline
\end{tabular}

Table II. - Maximum photoconductivity for virgin and posthydrogenated films.

\begin{tabular}{|c|c|c|c|}
\hline Treatment & & $\begin{array}{c}\text { Deposition } \\
\text { rate }\end{array}$ & $\begin{array}{c}\sigma_{\mathrm{ph}} \\
(\Omega \mathrm{cm})^{-1}\end{array}$ \\
\hline Virgin & a & $25 \AA / m i n$ & $210^{-7}$ \\
\hline 1 h. plasma & a $^{\prime}$ & $27 \AA / m i n$ & $710^{-9}$ \\
\hline Virgin & b & $63 \AA / m i n$ & $710^{-9}$ \\
\hline 1 h. plasma & b' $^{\prime}$ & $67 \AA / m i n$ & $1.510^{-7}$ \\
\hline Virgin & c & $145 \AA / m i n$ & $810^{-10}$ \\
\hline+1 h. plasma & c' & $151 \AA / m i n$ & $10^{-8}$ \\
\hline
\end{tabular}


or posthydrogenated films deposited at low $\left(\mathrm{a}^{\prime}\right)$ or high $\left(\mathrm{c}^{\prime}\right)$ rates have intermediate $\sigma_{\mathrm{ph}}$ values. In a-Si : $\mathrm{H}$ [1], hydrogen stick to the structural defects of the Si matrix and reduce their size. However, a residual defect always remains, its size increasing from $\mathrm{H}^{\prime}$ to $\mathrm{SiH}$ and then to $\mathrm{SiH}_{2}$. At low deposition rates, the hydrogen has stuck to all the structural defects that it can compensate. The film is saturated. For higher $v$ the films are not saturated.

For virgin films, the photoconductivity value decreases as the deposition rate increases, i.e. as the hydrogen concentration in the films falls further below saturation and, to a lesser extent as their relative $\mathrm{SiH}_{2}$ content increases. However, these effects are clouded by a parallel increase of the spin density (Table I). After one hour of posthydrogenation, the spin densities (Table I) remain similar to those in the corresponding virgin samples. When posthydrogenation leads towards hydrogen " saturation " the photoconductivity increases (from (b) to $\left.\left(\mathrm{b}^{\prime}\right)\right)$. When it increases the relative $\mathrm{SiH}_{2}$ content, the photoconductivity decreases from (a) to ( $\left.\mathrm{a}^{\prime}\right)$. The photoconductivity also increases when $\mathrm{SiH}_{2}$ has disappeared even when the posthydrogenation leads to a lower hydrogen content (from $(c)$ to $\left.\left(c^{\prime}\right)\right)$.

\section{Discussion.}

The maximum photoconductivity value $\sigma_{\mathrm{ph}}: 2 \times 10^{-7}(\Omega \mathrm{cm})^{-1}$ obtained here for intrinsic sputtered a-Si : $\mathrm{H}$ close to hydrogen saturation appears close to the maximum values reported for other intrinsic a-Si : $\mathrm{H}$ material exhibiting similar $E_{\mathrm{c}}-E_{\mathrm{F}}$ distances prepared either by glow discharge [6], or by sputtering [8]. We suggest here that changes in the photoconductivity originate from changes in the concentration and distribution of localized states. Other reasons have been suggested involving only a change in the position of the Fermi level within the same distribution of localized states in the bulk material or near interfaces. Anderson and Spear [4] report that a decrease of $E_{\mathrm{c}}-E_{\mathrm{F}}$ results in an increase of the photoconductivity on glow discharge films. On the contrary, we found that the increases of photoconductivity correspond systematically to increases in the activation energy of the dark conductivity (identified often [4] with $E_{\mathrm{c}}-E_{\mathrm{F}}$ ). So the variations of $E_{\mathrm{c}}-E_{\mathrm{F}}$ (Table I) cannot in any case explain those of the photoconductivity. The effect is particularly striking with posthydrogenation.

Recently, Solomon et al. [11] pointed out for glow discharge films the existence of band bending in the vicinity of the film-substrate interface. In fact, the comparison of the activation energy for dark conductivity measured on a coplanar or sandwich structure [3] does indicate downward band bending of about $0.15 \mathrm{eV}$ in agreement with Solomon et al.'s [11] results. However, this does not modify our conclusions because here the photoconductivity increases as $\left(E_{\mathrm{c}} E_{\mathrm{F}}\right)$ increases. In fact, the photoconductivity varies very much when the hydrogen concentrations on the various sites vary, even for the same dangling bond concentration. From their magnitudes, the variations of the $\mathrm{H}$ concentrations have to take place in the tissue. So the photoconductivity is mainly dependent on the tissue. Preferential modification of the tissue by low temperature $\left(T<400^{\circ} \mathrm{C}\right)$ posthydrogenation also explains the spread (with the " quality " of the tissue) between the diffusion coefficients reported for $\mathrm{H}$ in a-Si : $\mathrm{H}$ [1] and the identity here (or same order of magnitude in LPCVD [12]) for the dangling bonds concentration before and after posthydrogenation if they are mainly located within the islands. These locations otherwise coincide with the tendency to have well-defined point defects in the islands and continuously distributed defects in the tissue [5]. This posthydrogenation picture and the control of the photoconductivity by the tissue while the dangling bonds are in the islands explain the above results on sputtered films as well as the high photoconductivity obtained with high dangling bond densities $\left(\sim 10^{18} / \mathrm{cm}^{3}\right)$ in posthydrogenated LPCVD films [12].

Another important point is the negative effect of the $\mathrm{SiH}_{2}$ site. In the a-Si : $\mathrm{H}$ tissue, the localized states are expected to originate from $\mathrm{Si}-\mathrm{Si}$ back bonds of the $\mathrm{SiH}$ or $\mathrm{SiH}_{2}$ bonds [1]. In a structure largely dominated by tetrahedral $\mathrm{Si}-\mathrm{Si}$ bonds $([\mathrm{H}]<22 \%), \mathrm{SiH}_{2}$ is expected to leave a larger deformation than $\mathrm{SiH}$ [1]. A negative effect of the $\mathrm{SiH}_{2}$ sites was also pointed out on the 
quality factor of the forward current of the a-Si : H/Pt structures by Deneuville and Brodsky [13] and in the photoconductivity of sputtered a-Si : $\mathrm{H}$ by Jeffrey et al. [14]. As shown here, this is a direct effect of the $\mathrm{SiH}_{2}$ site which does not originate from dangling bonds [10] associated with this site when the $\mathrm{SiH}_{2}$ are as $\left(\mathrm{SiH}_{2}\right)_{n}$. This is striking from comparison of virgin and posthydrogenated samples (Table I).

\section{Conclusion.}

In conclusion, from our results, the photoconductivity is mainly limited by the tissue of the a-Si : $\mathbf{H}$ films, while the residual concentration of dangling bonds in these sputtered films is mainly in the island zone. Moreover, the compensation of the Si matrix defects by the hydrogen leaves a larger deformation around the $\mathrm{SiH}_{2}$ sites which directly induces a poorer photoconductivity with $\mathrm{SiH}_{2}$ than with $\mathrm{SiH}$ sites in a-Si : $\mathrm{H}$.

\section{Acknowledgments.}

We thank C. Bianchin and H. Matraire for their technical assistance, B. K. Chakraverty for fruitful discussions and R. Comes for financial support under contract A 650-5106.

\section{References}

[1] Deneuville, A., Bruyère, J. C., Mini, A., Kahil, H., Danielou, R. and ligeon, E., J. Phys. C 14 (1981) 2275.

Deneuville, A., Mini, A., Bruyère, J. C., J. Phys. C 14 (1981) 4531.

[2] Bruyère, J. C., Deneuville, A., Mini, A., Danielou, R. and Fontenille, J., J. Appl. Phys. 51 (1980) 2199.

[3] Bruyère, J. C. and Deneuville, A., J. Physique Lett. 41 (1980) L-31 ; C.R. Hebd. Séan. Acad. Sci. B 289 (1980) 2199.

[4] Knights, J. C. and Lujan, R. A., Appl. Phys. Lett. 35 (1979) 1244.

Reimer, J. A., Vaughan, R. W. and Knights, J. C., Phys. Rev. Lett. 44 (1980) 193.

JeFFrey, F. R., and Lowry, M. E., J. Appl. Phys. 52 (1981) 5529.

[5] Deneuville, A., Bruyère, J. C., Hamdi, H., Proc. 9th Int. Conf. on Amorphous and Liquid Semicond., Grenoble, 1981 ; J. Physique Colloq. 42 (1981) C4-733.

[6] Anderson, D. A. and Spear, W. E., Philos. Mag. 30 (1977) 695.

[7] SPEAR, W. E., Proc. 5th. Int. Conf. Amorphous and Liquid Semicond., Garmisch Partenkirchen, 1973. p. 1.

[8] Moustakas, T. D., J. Electron. Mat. 8 (1979) 391.

[9] Brodsky, M. H., Thin Solid Films 40 (1977) L-23.

[10] Knights, J. C., Lucovsky, G. and Nemanich, R. J., J. Non-Cryst. Solids 32 (1979) 393.

[11] Solomon, I., Dietl, T. and Kaplan, D., J. Physique 39 (1978) 1241.

[12] Bustarret, E., Ranchoux, B., Hamdi, H., Deneuville, A., Huant, S. and Depelsenaire, P., Proc. XVIe Conf. Physics Semiconductors, Montpellier, septembre 1982.

[13] Deneuville, A. and Brodsky, M. H., J. Appl. Phys. 50 (1979) 1414.

[14] Jefrekey, J. R., Shanks, H. R. and Danielson, G. C., J. Appl. Phys. 50 (1979) 7034. 